January 1992

\title{
Rethinking the Oedipus Complex
}

Daniel B. Block, M.D.

Thomas Jefferson University

Follow this and additional works at: https://jdc.jefferson.edu/jeffjpsychiatry

Part of the Psychiatry Commons

Let us know how access to this document benefits you

\section{Recommended Citation}

Block, M.D., Daniel B. (1992) "Rethinking the Oedipus Complex," Jefferson Journal of Psychiatry. Vol. 10 : Iss. 1 , Article 11.

DOI: https://doi.org/10.29046/JJP.010.1.010

Available at: https://jdc.jefferson.edu/jeffjpsychiatry/vol10/iss1/11

This Article is brought to you for free and open access by the Jefferson Digital Commons. The Jefferson Digital Commons is a service of Thomas Jefferson University's Center for Teaching and Learning (CTL). The Commons is a showcase for Jefferson books and journals, peer-reviewed scholarly publications, unique historical collections from the University archives, and teaching tools. The Jefferson Digital Commons allows researchers and interested readers anywhere in the world to learn about and keep up to date with Jefferson scholarship. This article has been accepted for inclusion in Jefferson Journal of Psychiatry by an authorized administrator of the Jefferson Digital Commons. For more information, please contact: JeffersonDigitalCommons@jefferson.edu. 


\title{
Rethinking the Oedipus Complex
}

\author{
SON AND FATHER: BEFORE AND BEYOND THE OEDIPUS COMPLEX \\ Peter Blos, Ph.D. \\ Free Press, New York, 1985 \\ $\$ 27.95$ \\ 186 pages
}

\section{Daniel B. Block, M.D.}

I just returned Peter Blos' book, Son and Father: Before and Beyond the Oedipus Complex, to my residency director and thanked him for providing me with such excellent and enjoyable reading material. But when I left his office, I became gradually aware of a sense of loss which I realized was directly related to relinguishing that book. At times compelling, at others purely enjoyable, Blos, in his eloquent and sophisticated style develops a brilliantly refreshing, original perspective of the Oedipus complex. The reader of this review might guess by my enthusiasm that this book moved me. But why, one might ask, the sense of loss? My answer is that reading this book transported me, touching off a chain of memories that led me through childhood and back to the present, back to my own thirteen month old son. It is a nostalgic sense of loss, sharpened by the reality of repetition-now I'm doing what my own father once did. ...

But back to the book itself. Blos essentially divides it into four distinct, but definitely intertwined sections. In the first section, he explains his own ideas about the father-son relationship, choosing to replace pre-Oedipal and Oedipal terminology with isogender (negative) complex and allogender (positive) complex. He focuses intently upon the dyadic relationship between the male child and the father, and highlights the father's role as an anchor against the regressive tide of re-engulfment by the symbiotic mother. He then looks anew at the triadic relationship of motherfather-son. Perhaps most important is his emphasis on the re-emergence of the isogender (negative) complex during adolescence-the dawn of adult sexuality. Blos underscores the importance of working through this complex during adolescence through de-idealization of the father on the road to emergence of a mature heterosexual identity. He also discusses the various points at which problematic aspects within the dynamics of these relationships sow the seeds for conflict in adulthood.

The next two sections have a common framework in that both present Blos' literary criticism. He first discusses Franz Kafka's undelivered letter to his father-a letter in which he bares his tormented, psychologically confused soul. Though weighty and convoluted at times, Blos analyzes Kafka's unresolved father complex in 
light of his earlier stated theories. The next section addresses Shakespeare's Hamlet. Blos analyzes Hamlet's inability to kill Claudius, his replacement "father," as his struggle to avoid the quicksand pull of the re-engulfing symbiotic mother. In both sections, Blos makes excellent use of quotations from the original texts to emphasize his analyses.

The final section discusses the development of gender identity and sexual identity from the initial infantile bisexuality up to adolescence, and the formation of mature heterosexuality. He highlights his points with relevant material from his own clinical experience. He also briefly attempts to explain feminine psychology, and the contrasting path a young girl must take to reach adulthood compared to boys. I'm not certain why he found it necessary to include that in this book, especially at the end of the text; it struck me as an afterthought. Overall, however, this book is a must read for any psychiatrist interested in more than prescribing psychotropic medications. It's quick reading, it's well-written, and it addresses a topic sorely in need of an update. 